\title{
PENGARUH LAYANAN INFORMASI TERHADAP KONSEP DIRI SISWA KELAS X- TSM SMK NEGERI PUTERA ANDA BINJAI TAHUN PELAJARAN 2016/2017
}

\author{
Haidir Ali, Angeline Hosana Zefanya Tarigan, Ali Muryati \\ STKIP Budidaya Binjai
}

\begin{abstract}
Abstrak
Penelitian ini adalah penelitian kuasi eksperimen dan dilakukan pada siswa kelas X-TSM SMK Putera Anda Binjai yang bertujuan untuk mengetahui seberapa besar pengaruh layanan informasi terhadap konsep diri siswa kelas X -TSM SMK Putera Anda Binjai Tahun pelajaran 2016/2017. Alat ukur yang digunakan dalam penelitian ini adalah skala konsep diri. Dalam penelitian ini, ada dua kelas yang digunakan, dimana satu kelas sebagai kelompok eksperimen dan kelas yang lainnya sebagai kelompok kontrol. Kelompok eksperimen diberikan layanan informasi tentang konsep diri, sedangkan kelompok kontrol tidak diberikan layanan informasi. Skala diberikan sebanyak dua kali untuk masing-masing kelompok yaitu satu kali pre-test dan kemudian post-test. Hasil penelitian yang menggunakan uji-t independent sample menunjukkan bahwa nilai $\mathrm{t}$ sebesar 4,310 dan $\mathrm{p}<0,01$. Artinya kelompok eksperimen memiliki perubahan yang signifikan dibanding dengan kelompok kontrol. Dengan demikian hipotesis penelitian ini diterima yang berarti terdapat pengaruh yang signifikan antara layanan informasi terhadap konsep diri siswa kelas X-TSM SMK Putera Anda Binjai Tahun Pelajaran 2016/2017. Hasil analisis menunjukkan bahwa nilai $F$ sebesar 0,457 dimana nilai $p>0,05$. Artinya tidak ada varians antara kelompok eksperimen dengan kelompok kontrol. Dengan kata lain variasi data pada kedua variabel kedua kelompok adalah sama. Dari hasil perhitungan juga dapat dilihat bahwa nilai signifikansi (p) untuk kedua uji $>0,1$, yang artinya data penelitian terdistribusi normal.
\end{abstract}

kata kunci : layanan informasi, konsep diri

\section{PENDAHULUAN}

Penting bagi individu untuk mengetahui tentang dirinya sendiri, karena ketika individu sudah mengetahui tentang dirinya, maka individu tersebut mampu berdaptasi ketika berinteraksi dengan lingkungannya. Untuk memahami dirinya sendiri, individu harus memliki konsep diri yang positif. Individu yang memiliki konsep diri yang positif akan memiliki sikap dan perilaku yang positif seperti tidak merasa malu dengan dirinya sendiri, adanya motivasi untuk menjadi pribadi yang lebih baik setiap hari, adanya tujuan hidup untuk meningkatkan potensi yang dimiliki serta memandang orang lain dari sudut pandang yang baik. Remaja adalah individu yang berada pada masa peralihan dari anak-anak menuju dewasa. Di usia remaja, mereka sudah diberikan tanggung jawab untuk dirinya sendiri dan orang lain. Meskipun belum sepenuhnya harus bertanggung jawab, namun remaja sudah dituntut untuk belajar menjadi seperti orang dewasa.

Bagaimana seorang remaja mampu mengemban tugas dan tanggung jawabnya sebagai anak di rumah, sebagai siswa di kelas dan sebagai teman di lingkungan sebayanya, tidak terlepas dari bagaimana konsep diri yang dia miliki. Remaja yang memiliki konsep diri yang 
positif cenderung mampu melakukan tugas dan tanggung jawab yang dibebankan kepada dirinya dengan baik. Namun pada kenyataannya hanya sedikit remaja yang memiliki konsep diri yang positif. Banyak remaja yang pada usianya tidak mampu mengidentifikasi dirinya sehingga mereka ikut-ikutan dengan teman sebayanya. Apabila yang menjadi contoh adalah remaja dengan konsep diri yang negatif, maka mereka juga akan memiliki konsep diri yang negatif. Mencontek, tidak masuk kelas pada jam pelajaran, melawan didikan orangtua dan guru, merokok, tawuran dan bentuk kenakalan remaja lainnya adalah itu sebenarnya. Kemampuan setiap siswa dalam mengenal konsep dirinya sangatlah berbeda-beda. Ada siswa yang mampu mengidentifikasi dirinya tanpa dipengaruhi teman sebayanya, namun ada juga yang tidak mampu. Bagi siswa yang mampu mengidentifikasi dirinya sendiri tanpa pengaruh dari lingkungan teman sebayanya, akan lebih bertanggung jawab untuk setiap hal yang dilakukannya. Sebaliknya siswa yang mudah dipengaruhi oleh teman sebayanya cenderung sulit untuk bertanggung jawab karena apabila terjadi kesalahan, maka siswa tersebut akan mencari kambing hitam atau menyalahkan temannya atau orang lain untuk kesalahan tersebut.

Hurlock menyatakan ada beberapa faktor yang mempengaruhi konsep diri, diantaranya adalah, "bentuk tubuh, pakaian, nama/julukan, inteligensi, cita-cita, emosi, gengsi sekolah, status sosial ekonomi keluarga, teman dan orang yang berpengaruh". Jika siswa menganggap semua faktor diatas adalah hal yang baik dalam dirinya maka hal ini menimbulkan perasaan yang positif (bangga, senang), maka muncullah konsep diri yang positif. Pada masa anak-anak, seorang individu umumnya cenderung membenarkan apa saja yang dikatakan oleh orang lain. Jika seorang anak merasa dia diterima, dihargai dan dicintai maka anak tersebut akan mampu menerima, menghargai dan juga mencintai dirinya sendiri (konsep diri yang positif). Sebaliknya jika orang-orang yang berpengaruh di sekelilingnya (orang tua, guru, orang dewasa dan temannya) ternyata meremehkan, merendahkannya, mempermalukan dan juga menolaknya, maka pengalaman itu akan disikapi dengan negatif (memunculkan konsep diri yang negatif).

Dari hasil observasi awal yang dilakukan peneliti di SMK Putera Anda Binjai, masih banyak siswa yang kurang memahami tentang konsep diri mereka masing-masing. Pada saat guru memberikan pembelajaran kepada anak didik, ada siswa yang lebih suka bermain dari pada memperhatikan guru, suka berbincang dengan teman sebangkunya, siswa yang sibuk dengan handphone, siswa yang mengganggu temannya yang serius belajar, bahkan juga ada siswa yang cabut ketika jam pelajaran dimulai, ini merupakan contoh perilaku dari siswa yang memiliki konsep diri yang negatif. 
Oleh karena itu agar siswa bisa memiliki konsep diri yang positif, dibutuhkan bimbingan dan arahan oleh guru bimbingan dan konseling (BK). Karena guru BK adalah guru yang memiliki peran untuk membimbing dan mengarahkan pesera didik agar peserta didik dapat mengikuti proses pembelajaran dengan baik sehingga mereka juga akan menjadi anakanak yang cerdas serta berbudi pekerti yang baik.

Salah satu layanan yang harus diberikan oleh guru BK kepada siswanya adalah memberikan layanan informasi. Layanan ini merupakan kegiatan untuk membekali para siswa tentang berbagai macam pengetahuan agar siswa mampu mengambil keputusan secara tepat dalam kehidupannya. Layanan informasi, sebagaimana layanan bimbingan dan konseling yang lain mengandung materi-materi terkait dengan tujuan yang ingin dicapai. Penyampaian materi terkait layanan informasi ini tentu akan lebih maksimal jika didukung oleh sarana dan prasaran yang memadai.

Layanan informasi "merupakan kebutuhan yang amat tinggi tingkatannya. Lebih-lebih bila diingat bahwa "masa depan adalah abad informasi", maka barang siapa tidak memperoleh informasi, maka akan tertinggal dan akan kehilangan masa depan". Winkel menjelaskan bahwa pengertian layanan informasi adalah: Layanan yang memungkinkan individu untuk memperoleh pemahaman dari suatu informasi dan pengetahuan yang diperlukan sehingga dapat dipergunakan untuk mengenali diri sendiri dan lingkungan. Layanan informasi juga bermakna usaha-usaha untuk membekali siswa dengan pengetahuan serta pemahaman tentang lingkungan hidupnya dan tentang proses perkembangan anak muda.

Apabila guru BK telah memberikan layanan informasi mengenai konsep diri yang positif kepada siswanya, diharapkan siswa juga dapat mengidentifikasi dirinya sehingga terciptalah konsep diri positif pada diri siswa. Semakin lengkap dan dapat dimengerti informasi yang diberikan guru kepada siswa, maka semakin tinggi pula tingkat keberhasilan layanan informasi yang diberikan. Berdasarkan penjelasan di atas, maka penulis ingin mengkaji lebih lagi mengenai konsep diri pada siswa. Oleh karena itu peneliti mengambil judul "Pengaruh layanan informasi terhadap konsep diri siswa kelas X -TSM SMK Putera Anda Binjai Tahun pelajaran 2016/2017."

\section{METODE PENELITIAN}

Penelitian ini akan dilakukan di SMK Putera Anda Jalan W.R Mongonsidi No. 22 Kelurahan Satria Kecamatan Binjai Kota, Kota Binjai Sumatera Utara. Sekolah ini sudah berdiri sejak tahun 1999 Penelitian ini akan di SMK Putra Anda Binjai tahun 2016. Penulis mengambil lokasi ini sebagai lokasi penelitian karena di sekolah ini terdapat permasalahan 
yang dapat diteliti dan di sekolah ini belum pernah dilakukan penelitian yang sama. Waktu penelitian dilaksanakan pada semester ganjil Tahun Pelajaran 2016/2017.

Menurut Kenth bahwa "populasi adalah seluruh koleksi orang atau unsur-unsur lain di mana peneliti akhirnya, atau populasi adalah jumlah yang harus diamati dalam penelitian". Sedangkan Sukmadinata mengemukakan bahwa populasi adalah "kelompok besar wilayah yang menjadi lingkup penelitian kita”. Populasi dalam penelitian ini adalah semua siswa kelas X SMK Putera Anda binjai Tahun Pelajaran 2016/2017. Populasi ini berjumlah 162 orang siswa yang terdiri 4 kelas.

Sugiyono memberi pengertian bahwa "sampel adalah sebagian dari jumlah dan karakteristik yang dimiliki oleh populasi". Selanjutnya Arikunto mengatakan bahwa "apabila subjeknya kurang dari 100, lebih baik diambil semua sehingga penelitiannya merupakan penelitian populasi. Selajutnya jika jumlah subjeknya besar dapat diambil antara 10-15\% atau $20-25 \%$ atau lebih". Adapun sampel penelitian ini berjumlah 40 orang siswa yang dipilih secara acak untuk kemudian dibagi menjadi kelas eksperimen dan kelas kontrol.

Metode penelitian ini menggunakan penelitian kuantitatif. Dalam pendekatan kuantitatif peneliti melihat apakah ada pengaruh layanan informasi terhadap konsep diri siswa kelas X-TSM SMK Putra Anda Binjai. Bentuk paradigma dari judul penelitian pengaruh sarana dan prasarana sekolah terhadap motivasi belajar siswa yaitu:

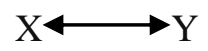

$\mathrm{X}=$ Sarana sekolah

$\mathrm{Y}=$ Motivasi belajar

Untuk memperoleh data yang akurat didalam penelitian ini, maka digunakan alat pengumpulan data sebagai berikut:

1. Angket.

Angket dibuat untuk mengetahui pendapat siswa mengenai konsep diri siswa. Angket juga dibuat untuk mengetahui apakah siswa memiliki konsep diri positif atau tidak.

2. Observasi.

Observasi yang dilakukan merupakan pengamatan terhadap seluruh kegiatan. Pada tahap ini observasi untuk melihat aktivitas siswa pada saat diberikan layanan informasi tentang konsep diri. 


\section{HASIL DAN PEMBAHASAN}

Penelitian ini dilakukan di kelas X-TSM SMK Putera Anda Binjai. Subjek penelitian ini adalah semua siswa dari kelas X-TSM Tahun Pelajaran 2016/2017. Berdasarkan metode pengambilan sampel yang sudah dijelaskan di bab sebelumnya, maka penelitian ini melibatkan 42 siswa sebagai subjek penelitian dengan rincian sebagai berikut :

\section{Subjek Penelitian}

\begin{tabular}{|l|l|l|}
\hline No & Kelompok & Jumlah \\
\hline 1 & Kontrol & 21 \\
\hline 2 & Eksperimen & 21 \\
\hline \multicolumn{2}{|l|}{ Total Sampel } & 42 \\
\hline
\end{tabular}

Penelitian ini merupakan penelitian quasi experimental yang menggunakan dua kelompok yaitu kelompok eksperimen dan kelompok kontrol. Pada penelitian ini, kelompok eksperimen diberikan layanan informasi tentang konsep diri, sedangkan kelompok kontrol tidak diberikan layanan informasi.

Dalam penelitian ini, dua grup yang digunakan sebagai kelompok eksperimen dan kelompok kontrol memiliki karakteristik yang hampir sama yaitu dari tingkat kognitif dan usia rata-rata di tiap kelompok sama. Masing-masing kelompok diberi pre-test dan post-test. Pretest untuk kelompok eksperimen diberikan sebelum layanan informasi diberikan. Tujuan diberikannya pre-test sebelum layanan informasi diberikan adalah untuk mengetahui keadaan awal masing-masing kelompok. Post-test untuk kelompok eksperimen diberikan setelah layanan informasi diberikan, dengan tujuan untuk mengetahui keadaan akhir masing-masing kelompok setelah diberikan layanan informasi.

Setelah dilakukan penetapan antara kelompok eksperimen dengan kelompok kontrol, peneliti kemudian memberikan skala konsep diri sebagai pre-test kepada kedua kelompok. Setelah itu peneliti memberikan layanan informasi hanya kepada kelompok eksperimen. Setelah itu secara bersama-sama peneliti memberikan skala konsep diri sebagai post-test kepada kedua kelompok.

Hasil analisis menunjukkan bahwa nilai $F$ sebesar 0,457 dimana nilai $p>0,05$. Artinya tidak ada varians antara kelompok eksperimen dengan kelompok kontrol. Dengan kata lain variasi data pada kedua variabel kedua kelompok adalah sama (homogen).

Taraf perbedaan pada kolom Equal Variances not assumed adalah 0,000 dengan nilai t sebesar 4,310 dan $\mathrm{p}<0,01$. Artinya kelompok eksperimen memiliki perubahan yang signifikan dibanding dengan kelompok kontrol. Dengan demikian hipotesis penelitian ini diterima yang 
berarti terdapat pengaruh yang signifikan antara layanan informasi terhadap konsep diri siswa kelas X-TSM SMK Putera Anda Binjai Tahun Pelajaran 2016/2017.

Berdasarkan hasil uji hipotesis diperoleh nilai $\mathrm{t}$ hitung $=4,310, \mathrm{t}$ tabel $=1,683$ berarti $\mathrm{t}$ hitung > t tabel pada taraf signifikansi 0,05, maka hipotesis penelitian diterima.. Hal ini disebabkan karena adanya pengaruh pemberian layanan informasi terhadap konsep diri. Setelah remaja mendapatkan informasi mengenai konsep diri, maka remaja kemudian memiliki pemahaman akan konsep diri yang benar dan baik bagi dirinya.

Seperti yang telah dikemukakan pada bab dua bahwa faktor yang mempengaruhi konsep diri adalah: keluarga dan lingkungan. Keluarga adalah orang tua yang berpengaruh besar terhadap perkembangan konsep diri individu. Bagaimana pola asuh dan didikan yang diterapkan orang tua kepada remaja akan sangat mempengaruhi konsep diri yang dimiliki anaknya.

Kemudian lingkungan sangat juga sangat berpengaruh terhadap pembentukan konsep diri remaja, terutama bagi orang yang mempunyai arti khusus bagi diri remaja itu sendiri. Lingkungan disini adalah lingkungan sekolah, tempat tinggal atau bersosialisasi. Lingkungan sekolah dalam hal ini guru dan teman sebaya di sekolah. Artinya guru juga memiliki peranan penting bagi terbentuknya konsep diri yang baik pada remaja.

Pada bab dua juga dikemukakan bahwa layanan informasi adalah salah satu kegiatan bimbingan konseling yang mampu memberikan informasi pribadi, sosial, karier maupun belajar untuk menambah wawasan siswa, mengenali dirinya (konsep diri) dan mampu menata masa depannya sebaik mungkin. Guru BK memiliki tugas untuk memberikan informasi mengenai konsep diri kepada siswa. Oleh karena itu apabila informasi mengenai konsep diri positif diberikan, maka siswa cenderung memiliki konsep diri yang positif pula.

\section{KESIMPULAN}

Ada beberapa kesimpulan dalam penelitian ini, antara lain :

1. Skor total kelompok eksperimen baik pada saat pre-test maupun post-test lebih tinggi dari pada kelompok kontrol.

2. Ada beberapa aitem dari skala yang tidak valid, karena nilai vailiditasnya dibawah 0,3 .

3. Dalam penelitian ini, sebaran data bersifat homogen dan terdistribusi normal.

4. Terdapat pengaruh yang signifikan antara layanan informasi terhadap konsep diri siswa kelas X-TSM SMK Putera Anda Binjai Tahun Pelajaran 2016/2017. Hal ini dikarenakan nilai t sebesar 4,310 dan $\mathrm{p}<0,01$. Artinya kelompok eksperimen memiliki perubahan yang 
signifikan dibanding dengan kelompok kontrol. Dengan demikian hipotesis penelitian ini diterima.

\section{REFERENSI}

Arikunto, Suharsimi. 2002. Prosedur Penelitian (Suatu Pendekatan Praktek). Jakarta: Rineka Cipta.

Berzonsky, M.D. 1981. Adolescent Development. New York: MacMilan: Publishing. Co Inc.

Calhoun J, \& Acocella R. 1990. Psikologi Tentang Penyesuaian dan Hubungan Kemanusiaan. Amerika Serikat: Trump Medium.

Dewa, Ketut Sukardi dan Desak Made Sumiati. 1989. Pedoman Praktis Bimbingan dan Penyuluhan di Sekolah. Denpasar: Rineka Cipta.

Gunawan, Yusuf. 1987. Pengantar Bimbingan dan Konseling. Jakarta: Gramedia Pustaka Utama.

Hastuti, Sri. 2006. Bimbingan dan Konseling di Institusi Pendidikan Yogyakarta: Media Abadi.

HM, Jogiyanto. 1999. Analisis dan Disain Informasi: Pendekatan Terstruktur Teori dan Praktek Aplikasi Bisnis. Yogyakarta: Andi Offset.

Hurlock, E.B. 2000. Psikologi Perkembangan: Suatu Pendekatan Sepanjang Rentang Kehidupan. Jakarta: Erlangga.

Kenth. 2008. Approach And Methods In Language Teacing $2^{\text {nd }}$. United Kingdom: Cambridge University Press.

Latipun. 2008. Psikologi Konseling. Malang: UNM Press.

Nurihsan, Ahmad Juntika. 2006. Bimbingan dan Konseling dalam Berbagai Latar Belakang. Bandung: Refika Aditama.

Paik, C.M., \& Micheal, W.B. 2002. Further Psychometric Evaluation of The Japanese Version of An Academic Self-Consept Scale. Journal of Psychology.

Sugiono. 1997. Sampel Penelitian. Bandung: Rosda Karya.

Sukmadinata, Nana Syaodih. 2011. Metode Penelitian Pendidikan. Bandung: Remaja Rosdakarya.

Tohirin. 2007. Bimbingan dan Konseling di Sekolah dan Madrasah (Berbasis Integrasi. Pekanbaru: PT Raja Gafindo Persada. 